\title{
Evidence linking familial thrombosis with a defective antithrombin III gene in two British kindreds
}

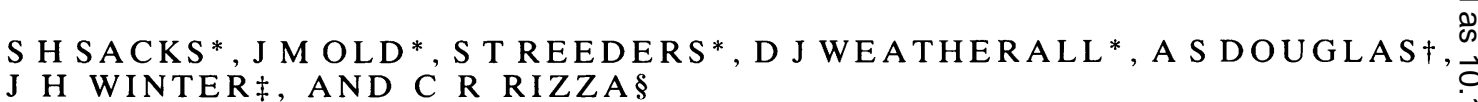

From * the Nuffield Department of Clinical Medicine, John Radcliffe Hospital, Headington, Oxford OX3 $\overrightarrow{\vec{\omega}}$ 9DU; †University Department of Medicine and Therapeutics, Aberdeen Royal Infirmary, Foresterhill,, Aberdeen AB9 2ZB; $¥$ Royal Infirmary, Glasgow G31 2ES; and \$Haemophilia Centre, Churchill Hospital,, Oxford.

SUMMARY Using DNA probes in a structural study of the antithrombin III gene locus we found no evidence of gene deletion in two British kindreds with inherited antithrombin III deficiency. However, linkage analysis between a common DNA polymorphism and the antithrombin $\mathrm{III}_{c}^{-}$ deficiency trait showed that the defect lies at or close to the antithrombin III structural gene. The lod score for linkage within the larger Scottish kindred was 3·1 $(\theta=0)$. These results are consistent with previously published data ${ }^{1}{ }^{2}$ suggesting that mutation of the antithrombin III structurak gene is the cause of inherited antithrombin III deficiency in some families.

Antithrombin III (AT III) is the main physiological inhibitor of thrombin, factor $\mathrm{Xa}$, and other serine proteases generated during coagulation. ${ }^{3}$ Familial deficiency of AT III results in marked predisposition to venous thromboembolic disease in adult life. The deficiency is inherited as an autosomal dominant trait and occurs with an estimated incidence of 1 in 2000 of the general population. ${ }^{4}$ Of those affected, 40 to $70 \%$ become symptomatic with recurrent and sometimes fatal peripheral venous thrombosis and pulmonary embolism at some time during their lives. ${ }^{4}$ Since the disorder was first described in $1965,{ }^{5}$ over 100 families have been described. ${ }^{6}$ In most patients with this disorder about half the normal levels of AT III protein are present, although on rare occasions deficiency of AT III anticoagulant activity is associated with normal levels of a structurally abnormal molecule. ${ }^{7-9}$ AT III deficiency trait has now been mapped to the long arm of chromosome $1 .^{10} 11$

In recent years, DNA probes for the AT III structural gene have been isolated. ${ }^{12-14}$ With these it has been possible to show genetic heterogeneity of inherited AT III deficiency. In one family, deficiency of AT III was attributed to deletion of the AT III structural gene, ${ }^{1}$ whereas in two other families the disorder was not associated with deletion of the AT III gene. ${ }^{12}$ We are investigating the genetic defect in two British kindreds with AT III deficiency. Here

Received for publication 16 February 1987.

Revised version accepted for publication 23 April 1987 we report the results of structural and segregation analyses at the AT III gene locus to suggest that AT III deficiency in these kindreds is the result of ao mutant AT III gene.

\section{Materials and methods}

We studied 29 members of a large Scottish kind-כ red $^{15}{ }^{16}$ (kindred a), and five members of an Oxford? kindred (kindred $b$ ) which has not previously been reported. Functional and antigenic levels of plasmao AT III in members of the Scottish family were measured as previously described. ${ }^{15} 16$ In the Oxford family, AT III functional activity was deter-ô mined by a modified progressive antithrombin assay, ${ }^{17}$ and AT III antigen levels were measured by electroimmunoassay. ${ }^{18}$ Two dimensional immuno- $\rightarrow$ electrophoresis of plasma AT III was carried out byㅡㅡ. the method of Sas et al. ${ }^{19}$

DNA was extracted from peripheral blood cells ${ }^{\circ}$ by standard procedures ${ }^{20}$ and $10 \mu \mathrm{g}$ aliquots of DNA were digested completely with restriction enzymes. N The resulting DNA fragments were separated byo electrophoresis in $0.8 \%$ agarose gels, transferred to nitrocellulose by the blotting procedure of Southern, ${ }^{21}$ and then hybridised to nick translated? ${ }^{32} \mathrm{P}$ labelled AT III DNA probes, as previouslyo described. ${ }^{20}$

Segregation analysis used two types of poly $\stackrel{\mathbb{D}}{\overparen{D}}$ morphic variation found at the AT III gene locus $\stackrel{\mathbb{D}}{\square}$ (1) a PstI restriction site polymorphism within thegene $^{13}$ revealed by hybridisation of a partial length 
1.1BLE 1 Functional and antigenic levels of plasma antithrombin III in members of kindred $b$ (Oxford family). The normal range measured in a group of healthy. controls was 80 to $140 \%$ of the average value in functional assays, and 80 to $120 \%$ of the average value in immunological assays.

\begin{tabular}{lll}
\hline & $\begin{array}{l}\text { AT III } \\
\text { functional } \\
\text { assay }\end{array}$ & $\begin{array}{l}\text { AT III } \\
\text { immunological } \\
\text { assay }\end{array}$ \\
\cline { 2 - 3 } & \% average normal & \\
\hline I.1 & 50 & 58 \\
I.2 & 90 & 100 \\
I.3 & 36 & 46 \\
II.1 & 94 & 74 \\
II.2 & 46 & 36 \\
II.3 & 64 & 28 \\
\hline
\end{tabular}

cDNA probe, pAT III-3 (a gift from S Orkin, Boston); and (2) a variable length polymorphism with two alleles located 345 bp upstream from the $5^{\prime}$ end of the gene, ${ }^{22}$ revealed by $A v a \mathrm{II}$ and the plasmid pAT 1.2 containing the $5^{\prime}$ flanking $1.2 \mathrm{~kb}$ PstI genomic fragment (a gift from S Orkin). Maximum likelihood analysis of linkage between polymorphisms and the AT III deficiency trait was carried out using the computer programme MLINK. ${ }^{23}$

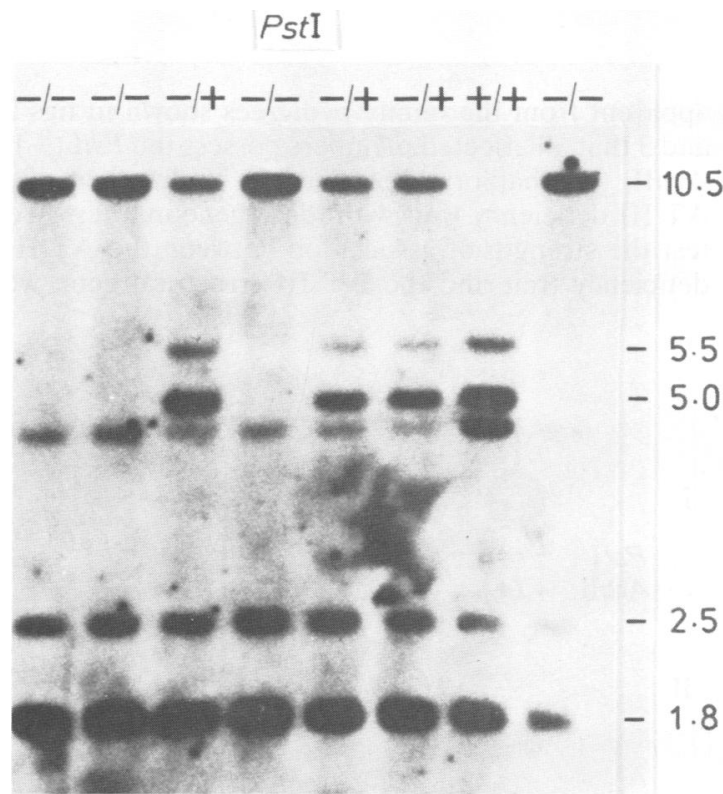

\section{Results}

The criteria we used to assign AT III deficiency to members of kindreds a and b were: (1) symptomatic thrombosis with reduced AT III activity and antigen; (2) reduced AT III activity and antigen in relatives without symptoms of thrombosis; and (3) a history of thrombosis in dead relatives. The cut off taken to define reduced levels of AT III was $<70 \%$ of the mean values obtained for a group of healthy subjects in both functional and immunological assays. Previously published data for kindred $a^{1516}$ show that both AT III functional activity and AT III antigen levels were reduced by about $50 \%$ in affected members (range 25 to $54 \%$ of normal in functional AT III assays, and 43 to $56 \%$ of normal in immunological assays). The results given in table 1 for kindred $b$ show a similar reduction in both functional and antigen levels to about $50 \%$ of normal. The AT III antigen in affected members of both kindreds showed normal mobility on two dimensional gel electrophoresis, suggesting that the AT III protein was qualitatively normal. That the deficiency was inherited as an autosomal dominant trait is evident from the family pedigrees (see below).

Fig 1 shows the PstI restriction site polymorphism and the AvaII variable length polymorphism used as

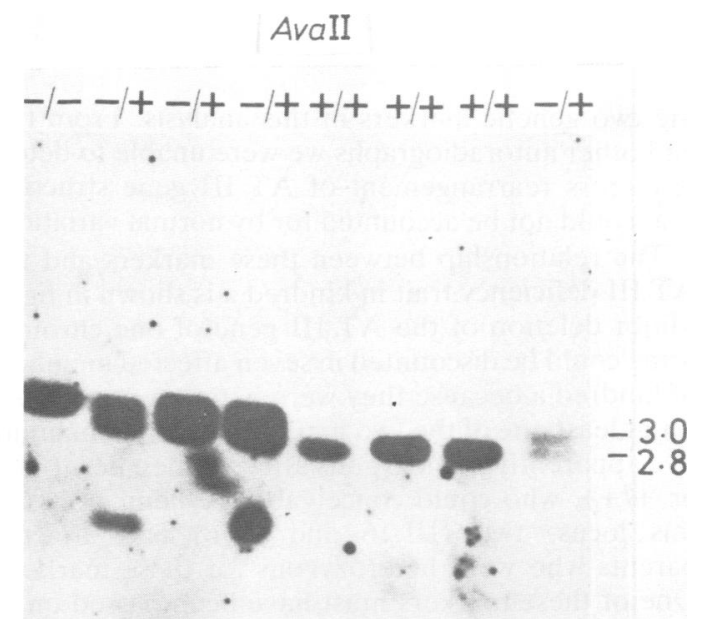

FIG 1 AT III DNA polymorphisms revealed by Southern blotting experiments. Blots of PstI digested DNA from eight subjects from kindreds $a$ and $b$ were hybridised with ${ }^{32} P$ labelled probe pAT III-3, and similarly AvalI digested DNA was hybridised with the probe pAT 1.2. The genotype with respect to each polymorphism is shown above each track and the numbers to the right indicate the approximate band sizes in kilobases (kb). The upper polymorphic bands of 10.5 and $3.0 \mathrm{~kb}$ are designated - , the lower bands of $5.5+5.0$ and $2.8 \mathrm{~kb}$ are designated + . 
$22 S$ H Sacks, J M Old, ST Reeders, D J Weatherall, A S Douglas, J H Winter, and C R Rizzo

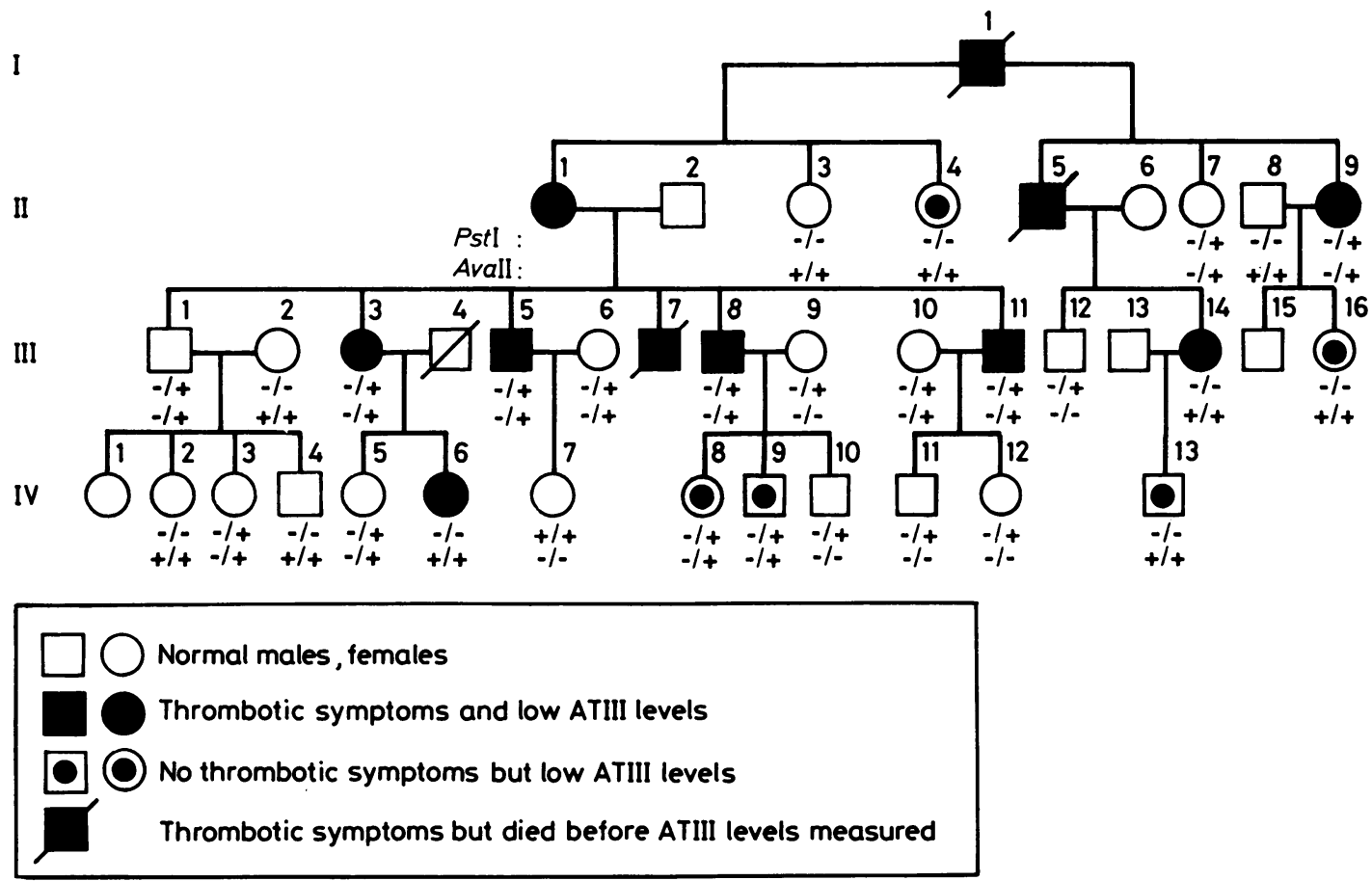

FIG 2 Pedigree of kindred a showing segregation of the two AT III DNA polymorphisms. Genotypes for the Pst $\bar{D}$ and Avall polymorphisms are indicated below each subject studied by DNA analysis.

the two genetic markers in this analysis. From this and other autoradiographs we were unable to detect any gross rearrangement of AT III gene structure that could not be accounted for by normal variation.

The relationship between these markers and the AT III deficiency trait in kindred a is shown in fig 2 . Major deletion of the AT III gene of one chromosome could be discounted in seven affected members of kindred a because they were heterozygous $(-/+)$ for at least one of the two markers. Of the remaining five apparently homozygous affected members $(-1-$ or $+/+$ ), who could conceivably be hemizygous at this locus, two (III.16 and IV.6) had affected parents who were heterozygous for these markers. One of these markers must have been passed on to the affected child, and therefore subjects III.16 and IV.6 must be truly homozygous. Similarly, any major deletion in kindred $b$ could be discounted in two affected members who were heterozygous for the PstI marker and in one apparently homozygous patient (II.2) who had an affected parent with heterozygosity for the PstI marker (fig 3).

The information from the two two-allele polymorphisms can be combined to generate four possible haplotypes $(--,-+,+-,++)$. It is apparent from the family pedigrees shown in figs $2 \frac{3}{5}$ and 3 that all affected members possess the Pst $\mathrm{I}(-)$, 王 AvaII (+) haplotype, suggesting linkage of the AT III deficiency trait with these gene markers. To test the strength of association between the AT IIldeficiency trait and the AT III structural gene we

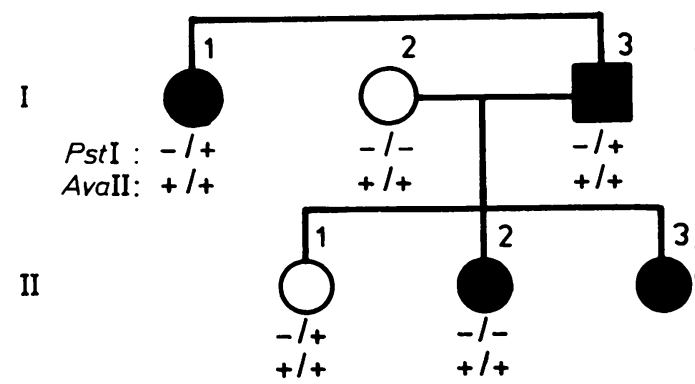

FIG 3 Pedigree of kindred $b$ showing segregation of the two AT III DNA polymorphisms. Affected subjects are indicated by solid symbols and genotypes for the PstI and Avall polymorphisms are shown for each subject studied. 
TABLE 2 Lod scores for linkage of AT III deficiency and Avall (+) length polymorphism in kindred $a$.

\begin{tabular}{ll}
\hline$\theta$ & Lod \\
\hline 0 & $3 \cdot 13$ \\
$0 \cdot 1$ & $2 \cdot 65$ \\
$0 \cdot 2$ & $2 \cdot 11$ \\
$0 \cdot 3$ & $1 \cdot 50$ \\
$0 \cdot 4$ & $0 \cdot 80$ \\
\hline
\end{tabular}

carried out linkage analysis in the larger Scottish kindred (kindred a) between the AT III deficiency trait and the AvaII + polymorphism. The results given in table 2 show that the maximum lod score for kindred a was $3 \cdot 13$ at a recombination fraction $\theta=0$ ( $95 \%$ confidence limits: 0 to $20 \%$ ). This is consistent with close linkage between the genetic defect which is responsible for AT III deficiency and the AT III structural gene.

\section{Discussion}

Deletion of an entire AT III structural gene has been implicated as the cause of AT III deficiency in three kindreds. ${ }^{10}$ In contrast, we were unable to show any structural abnormality of this gene in two British kindreds with AT III deficiency, even though phenotypically (proportionate decrease in activity and antigen) they were the same as the cases just cited. In both our kindreds two copies of the AT III structural gene were present and both alleles were normal. Extensive deletion was excluded by identification of the $-1+$ PstI genotype in seven affected members of kindred a and two affected members of kindred $b$. These results add to existing reports of two other kindreds in whom no evidence of AT III gene deletion was detectable by gene probing. ${ }^{12}$

The precise molecular defect in our families was not evident from the Southern blot data presented here. Small DNA deletions and single nucleotide changes can only be detected by Southern blotting if they occur at a restriction enzyme site. The majority of known molecular defects of single gene disorders do not occur at such sites, as in, for example, the thalassaemia disorders. ${ }^{24}$ These may only be characterised by gene cloning and DNA sequencing. Alternatively, the genetic defect in these families may be unlinked to the AT III structural gene. A precedent exists in the case of type I familial isolated growth hormone deficiency where disease trait and growth hormone structural gene markers segregated independently in linkage studies. ${ }^{25}$

Linkage analysis in the present study which compared segregation of the AT III deficiency trait and the AvaII DNA polymorphism clearly established linkage between AT III deficiency and the AT III structural gene, at a significance level of $p<0 \cdot 001$. This strongly suggests that AT III deficiency in our families was caused by a subtle defect at or close to the AT III gene locus. If this situation exists the,-+ haplotype that we identified in all the affected family members we studied must encode the defect on the basis of the linkage study of the affected parent II.9 and her affected offspring III.16 (fig 2). Cloning and sequencing of genomic DNA from an affected heterozygote with this haplotype might help to determine the precise molecular defect in this kindred.

During the course of this study, Bock et $a l^{2}$ published data on a Utah kindred, showing tight linkage between the same two AT III gene markers and AT III deficiency. Our data confirm these results, but interestingly AT III deficiency in our kindreds is linked to a different haplotype from the one reported by Bock et al (PstI+, AvaII-). This implies that more than one mutation has occurred leading to the non-deletion type of AT III deficiency. Furthermore, these differences at the genomic level may reflect heterogeneity that has been observed at the protein level. Most families with AT III deficiency display reduced levels of an apparently normal AT III protein, ${ }^{4}$ but on rare occasions the AT III molecule has been found to be structurally abnormal. $^{7-9}$ Our families belong to the first category, since we found no evidence of protein abnormality on two dimensional gels. In contrast, Bock et $a l^{2}$ were able to show abnormal electrophoretic behaviour of the AT III protein in affected members of the Utah kindred, suggesting that this family belongs to a different category from the families we have reported.

We are indebted to $\mathrm{Dr} \mathrm{H}$ C Drysdale and $\mathrm{Mr} \mathrm{M}$ Hancock for alerting us to their patient who is a member of kindred $b$, and to Dr D Godden for collecting some of the blood samples. We thank $\mathrm{Dr}$ S Orkin for generously supplying the AT III DNA probes, Miss A Fitches and Mrs C Heath for technical assistance, and Mrs L Roberts and Miss $P$ Wright for typing the manuscript.

\section{References}

1 Prochownik EV, Antonarakis S, Bauer KA, Rosenberg RD, Fearon ER, Orkin SH. Molecular heterogeneity of inherited antithrombin III deficiency. $N$ Engl J Med 1983;308:1549-52.

2 Bock S, Harris J, Schwartz C, Ward J, Hershgold E, Skolnick M. Hereditary thrombosis in a Utah kindred is caused by a dysfunctional antithrombin III gene. Am J Hum Genet 1985;37: 32-41.

3 Rosenberg RD. Actions and interactions of antithrombin and heparin. N Engl J Med 1975;292:146-51.

4 Thaler E, Lechner K. Antithrombin III deficiency and thromboembolism. Clin Haematol 1981;10:369-90. 
${ }^{5}$ Egeberg O. Inherited antithrombin deficiency causing thrombophilia. Thromb Haemostas 1965;13:516-30.

6 Strikwerda S, Van der Velden L, Swarf K, Geerdink R. Antithrombin III deficiency as congenital risk factor for venous thrombosis and embolism. Haematologica (Pavia) 1986;71: 407-10.

7 Sas G, Blasko G, Banhegyi D, Jako J, Palos LA. Abnormal antithrombin III (antithrombin III Budapest) as a cause of familial thrombophilia. Thromb Haemostas 1974;32:105-15.

${ }^{8}$ Wolf M, Boyer C, Lavergne JM, Larrieu MJ. A new familial variant of antithrombin III: antithrombin III Paris. $\mathrm{Br} J$ Haematol 1982:51:285-95.

${ }^{9}$ Sorensen P, Sas G, Peto I, Blasko G, Kremmer T, Samu A. Distinction of two pathologic antithrombin III molecules: antithrombin III 'Aaborg' and antithrombin III 'Budapest'. Thromb Res 1982;26:211-9.

${ }^{10}$ Winter JH, Bennett B, Watt JL, et al. Confirmation of linkage between antithrombin III and Duffy blood group and assignment of AT III to 1q22-q25. Ann Hum Genet 1982;46:29-34.

$"$ Bock SC, Harris JF, Balazs I, Trent JM. Assignment of the human antithrombin III structural gene to chromosome 1q23-25. Cytogenet Cell Genet 1985;39:67-9.

12 Bock SC, Wion KL, Wehar G, Lawn RM. Cloning and expression of the endogenous anticoagulant protein, human antithrombin III. Nucleic Acids Res 1982;10:8113-25.

${ }^{13}$ Prochownik E, Markham A, Orkin S. Isolation of a cDNA clone for human antithrombin III. J Biol Chem 1983;258:8389-94.

${ }^{14}$ Stackhouse R, Chandra T, Robson K, Woo S. Purification of antithrombin III mRNA and cloning of its cDNA.J Biol Chem 1983;258:703-6.

${ }^{15}$ Mackie M, Bennett B, Ogston D, Douglas A. Familial thrombosis: inherited deficiency of antithrombin III. $\mathrm{Br}$ Med J 1978;1:136-8.
16 Winter J, French A, Ridley W, et al. Familial antithrombin? deficiency. $Q J$ Med 1982;51:373-5.

17 Lane J, Bird P, Rizza C. A new assay for the measurement of total progressive antithrombin. Br J Haematol 1975;30:103-15.

${ }^{18}$ Laurell C. Quantitative estimation of proteins by electrophoresis in agarose containing antibodies. Anal Biochem 1966 15:45-54

${ }^{19}$ Sas G, Pepper DS. Cash JD. Plasma and serum antithrombin III: differentiation by cross immunoelectrophoresis. Thromb Res 1975;6:87-91.

20) Old JM, Higgs DR. Gene analysis. In: Weatherall DJ, ed. The. thalassaemias. Methods in haematology. Vol 6. Edinburgh: Churchill Livingstone 1983:74-102.

21 Southern E. Detection of specific sequences among DNA fragments separated by gel electrophoresis. J Mol Biol 1975;98:3 503-17.

22 Bock SC, Levitan DJ. Characterization of an unusual DNA length polymorphism $5^{\prime}$ to the human antithrombin III gene:Nucleic Acids Res 1983;11:8569-82.

23 Lathrop G, Lalouel J. Easy calculations of lod scores and genetic risks on small computers. Am J Hum Genet 1984;36:음 460-5.

24 Weatherall DJ, Clegg JB. Thalassaemia revisited. Cell 1982;29:c 7-9.

25 Phillips JA, Parks JS, Hjelle BL, et al. Genetic analysis of familial isolated growth hormone deficiency type I.J Clin Inves है 1982;70:489-95.

Correspondence and requests for reprints to Dr S $\mathrm{H}_{\infty}^{\infty}$ Sacks, Nuffield Department of Clinical Medicine John Radcliffe Hospital, Headington, Oxford OX 30 9DU. 